\title{
The Difficulties of Learning English: Perceptions and Attitudes in Mexico
}

\author{
Colette Despagne (University of Western Ontario)
}

\begin{abstract}
The political, cultural, and economical relationship between the United States and Mexico is becoming more interdependent, and in general, Mexico's participation in the world economy has increased the spread of English as a Second Language (ESL). English is ubiquitous in Mexico's everyday life, as opposed to indigenous languages which are mostly hidden. The diffusion of English makes ESL learning mandatory if Mexicans want to aspire to a better social and economic life. Nevertheless, this contextual 'imposition' highly influences perceptions and attitudes Mexicans have towards the language. This in turn may create a strong barrier to the whole language learning process. Based on student surveys in two different universities, this paper accents negative perceptions and attitudes towards English language learning, and highlights Mexico's colonial past and the effects of linguistic imperialism. In the conclusion, it will open the discussion on how these attitudes could be managed in the classroom, and will offer possible directions for future research in intercultural language learning.
\end{abstract}

\begin{abstract}
Résumé
La relation politique, culturelle et économique entre les États-Unis et le Mexique est de plus en plus interdépendante, et en général, la participation du Mexique sur les marchés internationaux a propagé l'enseignement de l'anglais en tant que langue seconde. L'anglais est une langue omniprésente dans la vie quotidienne du Mexique, bien au-delà des langues autochtones qui sont en général plutôt cachées. Pour qu'un mexicain puisse aspirer à de meilleures possibilités économiques et sociales, l'apprentissage de l'anglais devient indispensable. Cette « imposition » contextuelle influence cependant clairement les perceptions et les attitudes que les mexicains ont envers la langue et crée des obstacles souvent difficiles à surmonter lors de l'apprentissage de cette dernière. Cet article met donc l'accent sur les perceptions et les attitudes négatives envers la langue en se basant sur des sondages d'étudiants dans deux universités différentes. Il cherche à expliquer ce blocage en faisant ressortir le passé colonial du Mexique et l'influence de l'impérialisme linguistique. En conclusion, l'article invitera à discuter sur les différentes façons de gérer ces attitudes au sein d'une salle de classe et proposera quelques recherches futures pour l'apprentissage interculturel des langues.
\end{abstract}

\section{I - AN ANALYSIS OF PERCEPTIONS AND ATTITUDES}

Attitudes are learnt, and our perceptions towards languages will be influenced mostly through our parents', teachers' and peers' perceptions, which in turn will be defined based on the social context in which we are living. These perceptions 
will also depend on our own personal experience(s) with the language and its associated culture(s).

Before focusing on a more theoretical approach and define what attitudes really are, and how they may be created through the actual Mexican social and ethno linguistic contexts, I would like to begin with some concrete examples of attitudes towards English in two different university settings which will represent a starting point.

The first survey was conducted in May 2008, based on an online questionnaire with the Sphinx Millennium software (2003), with 300 UPAEP (Universidad Popular Autónoma del Estado de Puebla) students in A1 and A2 English classes, as per language levels based on the Common European Frame of Reference for language learning and teaching. They represented $8 \%$ of the total number of undergraduate students studying English at the UPAEP at that time, and the survey shows a $95 \%$ of reliability based on a quota sampling method (Despagne, 2008). Over 90\% of these students are situated between their 2nd and 4th semester of studies. Students had to answer the questionnaire during one of their daily English classes. The results of this survey on individual attitudes may not reveal attitudes exactly because some of the students may respond "in a way that makes them appear more prestigious, more good than in reality. "Consciously, and unconsciously, people tend to give socially desirable answers, and put themselves in the best light" (Baker, 1992:19). These results will nevertheless show a general attitude towards English in the context of a middle class private university setting in Mexico.

Students from the UPAEP come from different Mexican states - most of them from the center and the south - and from two different educational systems, the private and the public one. Eighty percent of these students begin to study English at the University in one of the first proficiency levels (level A1 or A2), a quite negative result for students who have already studied English for 3 or 4 years.

I discuss the following data based on a collection of 300 answers:

- $\quad 60.3 \%$ don't like the American culture:

- Students who graduated from the public school system feel more attracted to the American culture than students coming from the private school system because English means hope and better incomes; $53.6 \%$ of them have family in the US;

- Students coming from the private sector have more family members living in the US (63.2\%) than students coming from public schools because it is easier for them to get a visa. They however feel less attracted to the culture.

- $\quad 67 \%$ of the UPAEP learners think that Native English Speakers should learn another language. English should not always be the only lingua franca.

- $\quad 89.72 \%$ of the learners know that English is extremely important: 
○ $58 \%$ think that English will help them in everything;

○ $39.7 \%$ think that English will help them in many situations such as

- Helping them to find a better professional situation $(98.7 \%)$;

- Helping them to study for a master's degree in a foreign country $(95.3 \%)$.

- $\quad 45 \%$ feel that English is a difficult language to learn and $61.3 \%$ of these students are not attracted at all to the American culture.

These results clearly show that UPAEP students feel great extrinsic motivation in learning English. They are all aware of the fact that English is mandatory in order to find good employment and really important in order to study for a master's degree abroad. But are they motivated intrinsically? Will this extrinsic motivation become intrinsic and help them to study better English?

Subsequently, the collected data of this survey shows that negative perceptions are predominant because learners automatically perceive English, consciously or unconsciously, as being related to economic, political and sociocultural problems between the US and Mexico. They also think of Native English speakers as being ethno centrists and would like to see them speaking other languages.

In addition, several studies like the one of Marion Perrefort (1997) (cited in Castellotti \& Moore, 2002) show a clear correlation between the image learners form within themselves about a country and their ability to learn the language. In consequence, if this image is negative, the language will be perceived as difficult to learn. $61.3 \%$ out of the $45 \%$ who think that English is a difficult language, are not very attracted to the US.

These results clearly state that negative perceptions may be at the origin of problems in the learning process. It is therefore extremely important to analyze attitudes from a system thinking approach including the social and historical context.

The second example about the perception of English language is based on earlier research. The study describes attitudes towards the English language made by Chasan and Ryan in 1995 with 370 students from the UNAM (Universidad Nacional Autónoma de México), Mexico's biggest public university. The study clearly showed that these Mexican students had negative attitudes towards English because of North American interventions in other countries and their attitudes towards immigrant workers. Chasan and Ryan also explained that English classes were based on a translation methodology, and had no cultural teaching component at that time. This lack of cultural awareness towards the US could therefore, be at the origin of negative attitudes.

This paper will however focus on negative attitudes in another area but not excluding Chasan's and Ryan's conclusions. As I will describe below, 
Mexico's geographical, historical, economical and political situation is quite particular. This is the reason why, after defining what attitudes represent, I will focus on two important historical and contemporary aspects which influence the English learning process in an unconscious manner: colonialism and economic imperialism.

So, what exactly is meant by "perceptions" and "attitudes", and how will these concepts influence the foreign language learning process? According to Moore (2007), the notion of perception is an interdisciplinary notion, which refers to sociology, anthropology, socio linguistics, and social psychology, but it was first studied in philosophy by Locke and Hume at the beginning of the 18th century. In accordance with Stanford's Encyclopedia of Philosophy, Hume divided perceptions in two different categories: sensations - outward sentiments - and reflections - inward sentiments.

Language teaching, a mix of the previously mentioned disciplines, involves perceptions that are focused on reflections. This is to say that inward sentiments, which are not always recognized at the conscious level, are the origin of the learners' attitudes towards the language learning process. Barbot and Camatarri (1999) state that "the notion of perception refers to a group of attitudes and ideas, sometimes even stereotypes that the person conveys in an unconscious way which affects the student's learning process" (p. 58-59 translation mine). If we accept the educational paradigm stating that education leads to change, the negative perceptions will indeed be a barrier.

According to Riley (1989), attitudes depend on the "individual's perception of ethno linguistic reality" meaning that a learner's "behaviour as a member of a group and with respect to other groups, will vary according to his[her] beliefs about the linguistic situation; and language learning is a crucial aspect of that behaviour" (p. 67).

Beliefs therefore belong to the sphere of cognitive theories of behaviour and lead to different behavioural attitudes. The ethno linguistic reality of a Mexican indigenous family and how they perceive the English language will be quite different from that of an affluent Mexican family. Although both families live in the same country, they live in totally different and opposing realities.

David Lasagabaster (2006) proposes that Ajzen's (1988) brief and clear definition of attitude is "a disposition to answer in a positive or negative way in regard to an object, person, institution or event" (p. 393). My hypothesis will use Ajzen's definition of "attitude" because I believe that Mexicans' attitudes towards English will depend on how they perceive the power relationship between Mexico and the United States and their respective languages.

In this sense, there is a clear distinction between perception and attitude; perceptions being what "English" symbolizes to them and what they think when they learn that language. Perceptions of the language are at the origin of language attitudes, areas which have been studied separately. 
According to Colin Baker (1995:4), research on the origins of language attitudes has been very deficient. In this sense, I propose to define attitudes towards the language as being the obvious behavioural results of these perceptions, a readiness of action as defined by Rossenberg \& Hovland (1960, cited in Baker, 1995: 13)). The positive or negative attitude which has been created through the perceptions influences the motivation of the language learning process. A variety of research has already proved the cause - effect sequence of attitudes and motivation in relation with language learning (Gardner, 1985; Baker, 1988; Huguet, Lapresta, Madariaga, 2008). A positive attitude towards English creates a favourable input for the language learning process (Baker, 1992: 12).

Marion Perrefort (Castellotti \& Moore, 2002) also shows a high correlation between the image a learner has about a country and the perception of difficulty he/she feels in learning the language. If the image of the country is negative, the learner will feel problems in learning the language. This correlation is quite obvious in the case of UPAEP students: $61 \%$ of whom feel English as being a difficult language to learn, and who are not attracted to American culture at all. Nevertheless, attitudes are neither inherited nor static; rather they are acquired in a social context and not always at a conscious level. Attitudes can vary as they are influenced by perceptions of people, experiences, and contexts, and can therefore be modified (Baker, 1992). If it is determined where the negative perceptions come from, it is possible to analyze them and discuss them in a critical thinking classroom atmosphere. By critical thinking I refer to Matthew Lipman's definition which states that critical thinking is "thinking that (1) facilitates judgment because it (2) relies on criteria, (3) is selfcorrecting, and (4) is sensitive to context" (Lipman, 1991:116 cited in Boisvert, 2004:32). By making students aware of their perceptions, and discussing and critiqueing them, it is likely that they will be able to self correct themselves based on a contextual sensitivity, which will in turn, eliminate the barrier and fear they have towards English. We do not want learners to assimilate a new way of seeing the world by changing their perceptions, but we want them to be aware of these perceptions. We want them to understand what the term "English" means to them. This awareness will change their attitudes towards the language because they will be able to make a fundamental distinction between the learning process of the language on the one hand and their perceptions of what the language represents to them on the other. In their study with UNAM students, Chasan and Ryan (1995) are clear on that point: cultural teaching components must be included in order to increase cultural awareness, and allow spaces for being able to discuss cultural difference.

Dörnyei (2003) states that attitudes are created, and can be changed, through 4 factors: family, teachers, peers, and school. All these factors live in a social relationship which influences the learner. Attitudes can be created by extrinsic and/or intrinsic motivation, based on Deci and Ryan's Self Determination Theory (2000). By extrinsic or external motivation, one generally 
refers to motivation that comes from outside. Extrinsic motivation for learning English in Mexico can be associated by the fact that people who speak English may obtain better paid jobs. This is the case of UPAEP students: $58 \%$ of whom think that English will help them in everything, and 39.7\% feel it will help them in finding a better professional situation and in studying for a master's degree in a foreign country. However, intrinsic or internal motivation comes from the inside. In other words, students learn English because they like the language, the culture or because they like learning a new language. But, it seems that UPAEP students don't really feel intrinsic motivation. As mentioned previously, 61.3\% of them are not attracted at all to American culture. Usually, intrinsic motivation is associated with high educational achievement and enjoyment by students. It is also connected to positive potential of human nature (Ryan \& Deci, 2000). Sometimes extrinsic motivation can become intrinsic, but this is not always the case.

The relationship between motivations and attitudes led me to examine this topic from a macro point of view, studying Mexico and the United States' relationship with Mexico. Their history and their mutual dependency represent the background of their power relationship and part of Mexico's ethno linguistic reality.

According to Strevens (Kachru, 1992), the use of English has nothing to do with nationality and identity because one to two billion people speak it as a non - native language in the world (Crystal, 2003). According to a 2007 Mitovsky poll, $9 \%$ of Mexicans speak a language other than Spanish, $86 \%$ of them English and only 2\% French. The rest speak other, non specified languages. Being bilingual in Mexico is generally associated with speaking English as a foreign language. English is in fact the only important foreign language because it represents power and success. As can be seen in the analysis in the next section, those who speak English will have a better possibility to be integrated in the "dominant culture".

\section{II - MEXICO'S ETHNO LINGUISTIC REALITY AND USES OF ENGLISH IN EVERYDAY LIFE}

Mexico belongs to the periphery-English countries or the expanding circle countries as described in Kachru's sociolinguistic profile of English which "can be viewed in terms of three concentric circles" (Kachru, 1986). The Inner Circle refers to those countries where English created its "traditional cultural and linguistic bases"; the Outer Circle where it represents an "institutionalized nonnative variety" and where it is taught as a second language, former British colonies; and the Expanding Circle countries where English is taught as a foreign language. In Mexico, English does not have any direct historical nor governmental role; nevertheless, it is widely used as a foreign language.

Mexico also fits into Galtung's imperialism theory which follows a similar classification (Phillipson, 1992): 
- the dominant Centre countries, former colonizers (with their respective dominant international languages),

- the dominated Periphery countries, former colonies (third world or underdeveloped countries) who export raw materials and cheap labour force, as Mexico does.

Since the Spanish conquest in 1521, the official language has been Spanish; however, 68 indigenous languages (or linguistic variants) (INALI, 2008) are still alive in Mexico today. Even if the political constitution of Mexico defines itself as a pluri-cultural nation, these languages have an unequal power relationship towards Spanish, and English. Mexicans usually see these languages in a deceptive way as being "dialects" because, as Shapiro (1989) claims, "the Other" (the different one) is located most fundamentally in language, the medium for representing selves and others" (Pennycook, 1998). Pennycook (1998) believes that the way of representing minority languages as "dialects" is an unconscious and a direct result of colonialism. This result can also be related to Bourdieu's (1982) concept of habitus. The unconscious way of representing minority languages as "dialects" is the doxa, which represents the learned, deepfounded, unconscious beliefs, and values, taken as self-evident universals, that inform an agent's actions and thoughts. The habitus therefore reproduces these beliefs, and defines perceptions, and attitudes.

According to the National Commission for the Development of Indigenous People (Comisión Nacional para el Desarrollo de Pueblos Indígenas), the last census showed that Mexico's population was about $13 \%$ indigenous and $87 \%$ mixed (mestizos) in 2000. In fact, the main part of the Mexican population very clearly adopts some European/Western thought patterns. Consequently, the mestizo part of Mexico's population, which represents the dominant culture, still reproduces colonial discourses which to this day are embedded in their national culture. This colonial discourse will "legitimate" and "reproduce" the social forms of domination, just as it will "acknowledge" general "status quo" opinions as being self-evident (Bourdieu, 1982). It will, for example, accept indigenous languages being less important and English being a prestigious international language. As a result, English has been inserting itself into this multilingual country with an increasing potency since December 1994 when the country officially accepted neo liberalism as the government's political and theoretical framework due to its signing of the NAFTA (North American Free Trade Agreement).. This in turn allowed Mexico to open its doors to North American products from the United States and Canada.

English, more than any other language, cannot be detached from its original cultural context because it does not represent a neutral nor a transparent code. In Mexico, English is a synonym for the United States, "el gran Norte" (The Grand North), the American dream. The USA is the most important economic, political and military neighbour with a common border of 3141 kilometres (nearly 1952 miles). 
Officially English is taught as a foreign language which means that "it has no special standing but is simply just another language" (Strevens, 1982, p. 36). Nevertheless, in Mexico, English has a real special standing, and may be on its way to become a second language because it plays a large role in education, entertainment (TV, cinema) and tourism. If English becomes a second language, Mexico will move from Kachru's (1992) "Expanding" to "Outer" circle of English. Germany (Görlach, 2002) and Argentina (Graddol, 1997) apparently show a similar shift. In order to understand this shift, this paper will analyze the uses of English in Mexico's everyday life (broadcasting, education, labour market).

\section{ENGLISH IN THE MEXICAN'S EVERYDAY LIFE}

As mentioned before, English is used daily in communication. It is impossible to spend one day in Mexico without hearing English on the TV, reading it in the newspapers and advertisements, or seeing it on business shop windows (Baumgardner, 2006). The Mexican media uses several loanwords, which are defined as code switching by McClure and Mir (1995) because they are not simply borrowed from English but rather integrated into the Spanish language. The closer to the border, the more English is used. Its appeal is due to both, its role as an international language, and as a reflection of modernity and technological superiority. Cable or satellite programs are more than $50 \%$ in English. Some North American programs like CNN, History Channel and Bibliography are translated into Spanish but the cultural vision does not change. Phillipson's theory of linguistic imperialism explains this phenomenon as cultural imperialism as it imposes only one unique vision of the world as being the right one.

Education is another context in which English is immensely powerful. The Mexican education system can be divided in two: the public system where education is free and the private one where education is financed by the family or a nongovernmental source.

In the public education system, the SEP (Secretaría de Educación Pública), the national institution which defines Mexico's educational policies., English is currently mandatory from grade 7. However the states of Tamaulipas, Chihuahua and Nuevo León have recently introduced English for grades 1-6.

Despite educational reform, English teaching is known to be deficient as the teachers have no specialized didactical training; moreover, some of them do not even speak the language at an advanced level. Consequently, teaching is based on repetition drills, rote learning and memorization that do not help motivate nor develop communicative abilities in the language.

One of Mexico's educational difficulties is the ever increasing gap between public and private schools as far as learning is concerned.

Private education for school children can be divided in three levels: 
- the elite bilingual schools like the American, German or French schools, for example, whose first objective was to preserve the language of former immigrant colonies. Nowadays these extremely expensive schools all teach English and respond to the elite's expectations which are to acquire an international language in a prestigious school with a recognized educational level (Hamel, 2006). This can clearly be seen at the American School in Mexico City where the yearly fees for Lower School grades are about 107,570 Mexican pesos (7,171 USD). There is also a one time, non-refundable fee for all students enrolling for the first time of 40,000 Mexican pesos,

(2,670 USD). Students of these schools generally attain a high level of English;

- medium bilingual schools that try to answer the demands of the educational paradigm which is to create autonomous and critical learners who accept change as part of their lives and are at least bilingual;

- low and very low level bilingual schools whose first aim is strictly commercial. Mexican people call these schools "escuelas patitos" (literally "little duck schools"). Most of them do not help the students to acquire a good English level because the teaching methodology is quite traditional and the English level of their teachers is low. In Mexico there are many bad private schools that attract "clients" selling a bilingual education.

At the university level, English is also very important. It is mandatory to reach a high level in at least one foreign language (usually English), particularly in science and technologies. A high level of English is imperative for universities if they want to compete on international levels. Universities are ready to spend a lot of money to make their teachers and high level administrators not only speak English, but also better understand the Western vision of the world. Several private universities in Mexico require the TOEFL exam as a condition for students to get their degree. Also, the demand for the internationalization of education in Mexican institutions is increasing. Private and public colleges and universities focus on international alliances and agreements to provide joint programs, dual certification, and exchange programs for students and professors. Internationalization processes are a key strategy in the universities' curricula.

According to a market research report of International Business Strategies (2008), 6\% of Mexican ESL students travel abroad for intensive English programs; $95 \%$ of them visited Canada, Great Britain or the US. In 2006, the US received 827 students (IIE, 2008), Canada 3,500 and Great Britain 3,000 . Canada is the preferred destination because of lower visa requirements. This research report also states that "the Canadian Embassy in Mexico processes an estimated 50,000 to 60,000 requests for information on educational programs 
per year" (p. 7) and the "British Council about 20,000 requests for information on educational programs per year" (p. 7).

Another research report of International Business Strategies (Graduate Education in Mexico, 2008) states that CONACYT (National Council for Science and Technology) supports postgraduate studies with grants and scholarships in more than 32 countries but that in $200231.8 \%$ of these grants went to the US, $25 \%$ to the UK and $7.2 \%$ to Canada, a total percentage of $64 \%$ goes to English speaking countries.

As a result, the English Teaching industry has become a highly interesting area for investments. As the former director of the British Council stated in his 1987/1988 annual report

Britain's real black gold is not North Sea Oil but the English language. It has long been at the root of our culture and now is fast becoming the global language of business and information. The challenge facing us is to exploit it to the full. (Phillipson, 1992:49)

English teachers will always find teaching positions in Mexico. MEXTESOL, an affiliate of TESOL Inc. is getting more and more important. According to Wilson (2006), the 2006 convention in Guanajuato lasted four days and had over 200 representatives from 31 Mexican states as well as speakers from the US, Britain, and Canada. English coordinators from important universities were invited on a free basis by publishers in order to market and sell English textbooks. In every Mexican city you will find a huge package of private English institutes selling English classes at a low cost based on traditional and/or invented learning approaches. Their objective is merely commercial due to English being a marketable product which adheres to the law of the linguistic market (Calvet, 2002).

Education prepares individuals for the labour market, another area where English is obviously highly important. With the internationalization of the world market and the US being the largest foreign investor in Mexico, English has become an essential requirement for any position. As a consequence of the current economical crisis, job advertisements generally ask for a high level of English, even if it will not be used.

With all this in mind, we can easily observe that English has become a highly valued product and more in Mexico than anywhere else because of its geographical position. Mexico belongs to the monetary dollar zone which means that the Mexican peso is defined based on the dollar, much more than based on the Euro or Canadian dollar. These monetary zones create unequal relationships because the dollar can buy any other currency. In fact, different shops such as OXXO even accept payment in dollars. They hang up a sign at the door entrance which says: "Aceptamos sus dólares a 14 pesos"(We accept your dollars at 14 pesos.) The exchange rate changes from one day to another depending on the devaluation of the peso but as the dollar exchange rate grows, so does the value 
of the English language. We are confronted with the commercial value of the language in a language market where English is nowadays the most expensive (Calvet, 2002).

Because of the value of this language and, a particular Mexican ethno linguistic reality, Mexicans have different feelings in relation to English, which in turn influence their language learning process. The following section of the paper will focus on positive and negative perceptions by explaining the results of UPAEP and UNAM students' perceptions towards the English language, which have been described previously, at the beginning of this paper.

\section{III - PERCEPTIONS AND ATTITUDES MEXICANS HAVE TOWARDS ENGLISH}

The perceptions Mexicans have towards the English language are generally quite divided. English is a synonym of hope and a better way of life; however, it ignites images of invasion and imperialism (Kachru, 1986; McArthur, 1998; Chasan \& Ryan, 1995). It seems to be a love/hate relationship which would be difficult to categorize according to social income levels or according to ideological references. In this paper I examine some of these positive and negative perceptions, as exemplified in the results of the UPAEP and the UNAM surveys.

All Mexicans know that English is the language of the elite, of the international commercial interdependence, of the technological revolution and of communication. They all know, as UPAEP or UNAM students do, that English is essential in order to succeed in a professional environment.

\section{Positive perceptions}

Positive perceptions towards English generally refer to international business possibilities, use of a lingua franca, technological development, communication, bilingual education and therefore study abroad possibilities, international job offers, better incomes, more power and respect. Speaking English opens the door for admission into the "dominant culture". Nearly $90 \%$ of UPAEP learners know that English is extremely important, and almost $99 \%$ of them think that it will help them in their professional growth.

In general, Mexicans with a high proficiency level in English are part of the elite. As mentioned before, most of the elite went to private schools where English is taught as a second language. Some of them even studied at least a semester abroad or completed a master's degree in a foreign country. Most well educated Mexicans believe in the benefits of internationalization and globalisation. They also consider English as a lingua franca which helps in international communication. They like buying American or European products because they think their quality is "better" and because of the social status these products represent. They have a passport and often travel to North American or European Center Countries, and usually have good paying jobs and a relatively 
high social status. In addition, this population usually does not mind using English loanwords in Spanish as English is part of their daily life.

Mexican elites do not really see nor accept that Mexico still lives under a colonial system as they belong to the dominant culture and also are a product of colonisation (Pennycook, 1998). They consciously or unconsciously accept the continuing colonial relationship with indigenous people (and lower social levels) and use these images of Self and Other or Us and Them. According to Pennycook (1998), Western/European cultures are not only at the origin of colonialism, they are also a product of it. Consequently, English can also be seen as a product of colonialism and we therefore can relate it to Mexican elites. In fact, most Latin American elites, Columbian (Velez-Rendon, 2003), Argentinean (Friedrich, 2003) or even Peruvian (Niño Murcia, 2003) possess a Western vision of the world. English is the expression of this vision and is generally taught through it.

Mexican elites are connected to Spain when they do not speak English and to the US when they speak it. Their interests are generally related to the Center countries. Most rich and middle class families want their children to study in a Center country. About 20,000 Mexicans students studied abroad in $2005,18,225$ of them in countries belonging to the Organisation of Economic Co-operation and Development (OECD). 55,000 of them study in Mexican universities which receive direct foreign investments from consortiums like the Laureate Education Inc. which administrates the Universidad del Valle de México (Rodríguez Gómez, 2005). The Universidad de Las Américas (UDLA) in Puebla and Mexico City is another example of how western ideals are taught through English language. When all these students come back to Mexico, they tend to favour the Centre countries' vision and reinforce the unequal and imperialistic structure. In Chrisman \& Williams' (1994) opinion, the actual imperialistic system of inequalities directly reflects the identification with the western capitalist mode of production. But only a very few Mexicans can afford a bilingual education which creates a coordinated (Weinreich, 1953), additive (Lambert, 1974) and egalitarian (Hagège, 1996) bilingualism.

\section{Negative perceptions}

Negative perceptions towards English among Mexicans usually refer to US imperialism (political, cultural and economical) as referred to in Chasan and Ryan's study (1995) with the UNAM students, immigration and border problems, racism and discrimination, images of Self and Other, dominant and dominated, invasion of North American products and businesses, market dumping policies, and too often use English words in Spanish.

Nearly 9.9 million Mexicans born in Mexico live in the United States nowadays and between 2000 and 2004, around 400000 Mexicans immigrated each year (CONAPO, 2004) to the US. The "remesas", that is, money Mexican 
immigrants working in the US send back home to their families, represents the second highest income after the country's oil production. There are many villages in Mexico that have lost most of their male population because they went to work to the US. Last year I had the opportunity to visit a rural school in Chalchihuapan, a little village near Puebla. I talked to the pupils of K6 and asked them if they had family in the US. Most of their fathers and brothers were living there, and their dream was to finish secondary school and then immigrate to the US. They did not see any future in Mexico. For them English is a synonym for survival which leads to better incomes for their families but also leads to abandonment, loneliness, exploitation, discrimination and hard work. The stories told by the members of their families are not always very positive. First, it is very hard to get to the US as illegal immigrants, and in the past 12 years, 4,000 immigrants have died trying to cross the border; 15 times more than the number of people who died crossing the Berlin wall during a 28 years period. In 2005, 473 illegal immigrants died, 260 in the desert of Arizona. See http://www.womenontheborder.org/documents/USAMexiquemigran488esp.pdf. Secondly, discrimination and labour exploitation is evident in the US. But in many cases, the US remains their only hope of better wages even at the cost of being separated from their families which is a significant part of the Mexican culture.

\section{IV - ORIGINS OF NEGATIVE PERCEPTIONS}

Research into perceptions and attitudes cannot only take into account the ideological phenomena, being for or against neo liberalism. Research cannot explain a positive or negative attitude towards a language based only on the acceptance or rejection of the ideology it represents. In Mexico, we have to examine it a bit further. So, why do $60.3 \%$ of UPAEP students say that they do not like American culture? Why do $67 \%$ of them think that English should not always be the only lingua franca? Structural connections have to therefore be analyzed. By structural connections, I refer to communication, trade, politics, military, and all the structure which supports social life and will or will not favour the immersion of a foreign vision into a home culture. "The English language is deeply interwoven with the discourse of colonialism" (Pennycook, 1998) and Spanish colonialism totally adheres to the discourse of English colonialism. Both are part of the western "dominant culture".

In this sense, I base my analysis on Galtung's imperialism theory referred to by Phillipson (1992) because it can help to explain the Mexican socio cultural shift from a colonial state to a state which facilitates a clear linguicism or linguistic imperialism.

The first concept, linguicism, must be attributed to Skutnabb-Kangas (1988) who gave the following definition: 
ideologies and structures which are used to legitimate, effectuate, and reproduce unequal division of power and resources (both material and non-material) between groups which are defined on the basis of language.

Linguicism refers to a social discrimination based on linguistic competencies, whereas linguistic imperialism, a concept analyzed by Phillipson (1992) refers to the direct or indirect imposition of a dominant language to other people.

The following lines will explain why both concepts can be totally validated in Mexico, and how they can be linked one to another.

Mexico had been colonized by Spain until 1810. The bicentenary of its independence will take place in 2010. Mexicans are obviously very proud to be free of colonial shackles and are therefore very fervent towards what they call the Mexican patriotic symbols which are the anthem, the flag and the emblem. These symbols show the syncretism between indigenous and western origins which create the "Mexican National Identity". Nowadays, all the Mexican school children must sing the national anthem every Monday morning and honour the flag as part of their culture. The objective of this weekly exercise aims to maintain national identity through the three guarantees of the "Ejército Trigarante", one of which is being independent. We have to remember that the Revolutin in Texas in 1836 and the 1848 war led to the fact that Mexico lost 116000 inhabitants, half of the territory and three quarters of the country's natural resources (Maciel, 1996).

Mexico is actually trying to guide itself towards a democracy. Living near the US and having them as their major economic partner is sometimes very difficult because of the power they represent. Referring to them as an imperialistic power is even more difficult to accept, from both sides because it shows the unequal power relationship, dominance, and obedience. As I do not want the imperialism concept to be misunderstood, I will first explain what I mean by it and how this concept connects with linguistics and the English learning process.

The term imperialism can be very ambiguous as it was used in the nineteenth century embracing "both an economic order and wider civilizing goals" (Phillipson, 1992).

In this paper, I refer to an economical imperialism "understood primarily as an economic system of external investment and the penetration and control of markets and sources of raw materials" (William, 1976 cited in Phillipson, 1992). Mexico exports raw materials like petrol and products from maquila, assembly plants which offer a cheap labour force. It leads Latin America in attracting foreign investment. 40\% of Mexico's foreign investment comes from the United States (BIIP, 2006). In every major city, there is a Walmart which has 1210 units distributed over 227 cities all over Mexico. (See http://www.walmartmexico.com.mx/index_english.html). The Mexican middle 
class goes shopping at Costco or at Sam's Club (which belongs to Walmart) and has coffee at Starbucks. Coca Cola is everywhere even in the most hidden place of the Lacandona jungle. Indigenous people from San Juan de Chamula in Chiapas even use it for their religious ceremonies, an interesting fact which shows how traditional cultures also introduce "modernity". As has already been noted, English is used in entertainment, radio, internet, publicity, businesses, shops, etc. In the major touristic areas like Cancun, everybody speaks English on the street. Consequently, there is an imperialistic structure that comes from an economic vision. This economic vision must, nevertheless, be coupled with other types of imperialism as the political and communicative ones.

This economic imperialism created its roots a long time ago during the colonial period. The case of Mexico is particular because it first was a Spanish colony and now it is mostly linked to the US because the US has brought the "modern world" to Mexico. Actual imperialism is related to colonialism because it creates a certain "state of mind" in Mexican culture. Colonialism created a class based society divided between dominant and dominated cultures. This relationship creates this special "rejection" to English in a very unconscious way as English represents the symbol of the dominating culture such as imperialism. Unconsciously Mexicans are afraid to be colonised again. The English language represents the means by which imperialism is made possible. It widely opens the doors to communicative and cultural imperialism (Schiller, 1976). English is mandatory in most universities. Other dominant languages such as French or German are generally optional and indigenous languages are rarely taught in Mexico. The language relationship in Mexican society is a clear expression of a class based society where English became the most important one, followed by Spanish and at last all the vernacular languages used only in intimacy, and only by indigenous people.

Language departments invest much more in English teacher training or in English curriculum development than in any other language. That is what Skutnabb-Kangas (1988) calls linguicism, when priority is given to only one single language. Phillipson (1992) defines English linguistic imperialism as one part of linguicism when "the dominance of English is asserted and maintained by the establishment and continuous reconstitution of structural and cultural inequalities between English and other languages". In Mexico, linguicism refers obviously to English but in some African countries it could also refer to French.

Linguicism may also be based on anglocentricity, which refers to language and culture, as well as professionalism which refers to pedagogy of English training. Anglocentricity puts the Anglophone vision of the world on the top, over the local one. This is not only the case of English. In the same way one could also speak about "francocentricity" or "germanocentricity". This is a general disease of all Centre countries' citizens.

Two other points favour linguicism: 
- the fact that most Mexican schools or universities adopt English teaching methods or materials created in the Centre countries which reinforces anglocentricity and,

- the fact that research and investments are logically made by rich countries which leads to the imposition of their vision of the world.

Spanish teaching textbooks, for example, are generally created in Spain and teach the Western vision of the world. The UNAM created however, Mexico's first Spanish method (Santillana, 2008) based on the Common European Framework of Reference last year in order to teach Spanish to the world from Mexico's (or Latin America's) point of view, which is quite different from the Spanish European one. Ultimately, the Instituto Cervantes also tries to incorporate Latin America's vision in the teaching of Spanish in order to diminish the European's ethnocentricity.

The British Council is another interesting example for English even if in Mexico most of the teaching materials come from the United States. The biggest problem in importing teaching materials is that they are not adapted, nor connected, to the local socio cultural reality, that they offer only one vision of the world, the western one, and that they ignore the mother tongue of the learners.

Teaching materials for Mexicans should be created in Mexico because Mexican students' backgrounds are quite different from, for example, Asian students' backgrounds for whom the teaching materials are also used. The material created in the Centre countries does not take into account the cultural nor the linguistic differences of each country and imposes its own thought patterns. Each culture develops linguistic abilities in different ways. Mexican students have a huge gap in written culture, for example, and Asian students' will have more problems in oral communication (seen from a Western point of view). So how can both teachers use the same teaching way and the same material? How can they instruct on the same basis when students' educational and cultural experiences are so different? Teaching materials and methodologies should be adapted or created according to each special cultural and educational background. They must build new knowledge in relation to the students' background. That is what the new educational paradigm is about, a student centered education.

For all these reasons, the imports of technologies, teaching materials, English broadcasting, the acceptance of English as being the most important foreign language and in general the way of looking at Western countries as being an example to follow is in fact the acceptance of being ruled by imperialistic powers. This approval leads Mexicans to feel inferior to this external power as they felt inferior to the Spanish colonists. As a result, $45 \%$ of UPAEP students feel that English is a difficult language, and that it carries too much weight. This power relationship is therefore reflected in the negative perceptions towards the English language and creates negative attitudes towards 
the English learning process. Mexicans, however, know that English is essential for their "survival" and this awareness and extrinsic motivation increases their fear even more. English is, therefore, a heated discussion subject.

These blockages are very difficult to dissolve. Learners only succeed once they are conscious of their perceptions towards the language and what it represents to them. A contextual understanding of these perceptions will lead to a conscious recognition of their attitudes towards the language and its learning process.

\section{CONCLUSION}

Opening the gateway of perceptions can be very dangerous if teachers do not develop a critical thinking atmosphere in the classroom. In other words, they will have to discuss perceptions towards English in the classroom, not to blot out negative perceptions in order to wholly accept western images of the world, but rather to analyse these perceptions in order to make learners conscious. They have to critically discuss them with the students' and from students' perspectives. This consciousness should open the gateway to learning English seen as an international communication language without associating it with dominating cultures. We do not want to convince students about the benefits or disadvantages of western thought patterns, we want them to keep their own patterns but based on sustainable arguments. We will never promote cultural assimilation but will try to develop intercultural understanding and intercultural communication in terms of synergy which will be likely to stabilise learners' self-identity (Meyer, 1991 quoted in Byram \& Fleming, 1998). I therefore propose learners to become "intercultural speakers", to focus on their native language and culture in order to build the learning of the new language by integrating their actual knowledge. Learning English does not mean to accept the new culture with closed eyes, to forget the native environment and assimilate the new one by trying to approximate the native speaker (Byram \& Zarate cited in Kramsch, 1998). Beginning with extrinsic motivation towards English in intercultural classroom settings may be a very helpful step, first to rehearse the awareness of native language and culture, and second by making learners feel more confident. This self confidence will make them feel more positive about their origins and will therefore avoid cultural assimilation. Once this second step has been reached, teachers may focus on intrinsic motivation, which is, as we discussed in the paper, connected to positive potential of human nature (Ryan \& Deci, 2000).

Cummins' Transformative Multiliteracies Pedagogy (2006) may be very helpful because it focuses on student empowerment through cognitive processing, language processing and identity investment (Lopez-Gopar, 2009). It builds on changing coercive power relationships between dominant and dominated groups into collaborative power relationships. Cummins' theory looks for a structural change in the whole educational discourse because it relies 
on linguistic and cultural diversity instead of destroying it by adopting the official discourse of dominant groups.

In any case, we do not have to forget that opposition to English also has its positive sides because it increases the defence not only of the Spanish language which is guided through the Spanish Language Academies of Latin America, dating back to 1875 in Mexico and dedicated to watch over the conservation, purity and the improvement of the Spanish language but also of the 62 Mexican indigenous languages. Opposition to English may therefore also reinforce Mexico's national identity.

I would like hereby to thank all the critical contributions, corrections and ideas of the following persons who made the publication of this paper possible: Shelley Taylor, Suzanne Majhanovich, Julie Byrd Clark, Robert Phillipson (providing helpful feedback on an earlier version of the paper), Helen Kelly, Duane Betts, and the unknown reviewer. Thank you!

\section{References}

Ajzen, Icek (1988). Attitudes, personality and behavior. Milton Keynes, Open University Press.

Baker, Colin (1988). Key issues in Bilingualism and Bilingual Education,Clevedon, Multilingual Matters

Baker, Colin (1992). Attitudes and language. Multilingual Matters.

Barbot, Marie-José \& Camatarri, Giovanni. (1999). Autonomie et apprentissage. L'innovation dans la formation. Éducation et Formation. Pédagogie théorie et critique, PUF.

Baumgardner, Robert (2006). The appeal of English in Mexican commerce. In World Englishes, Vol. 25, No 2, pp. 251-266.

Boisvert, Jacques (2004). La formación del pensamiento crítico. Teoría y práctica. Fondo de Cultura Económica. Educación y Pedagogía.

Bourdieu, Pierre (1982). Language and symbolic power [Ce que parler veut dire] (Gino Raymond and Matthew Adamson Trans.). (1991st ed.). Cambridge, Massachusetts: Harvard University Press.

BIIP (Bureau of International Information Programs, US Dept. of State) (2006).

http://www.america.gov/st/washfileenglish/2006/April/2006041331349211xeneerg0.5191614.html.

Byram, Michael \& Fleming, Michael (Ed.) (1998). Language learning in Intercultural Perspective. Approaches through drama and ethnography. Cambridge Language Teaching Library.

Calvet, Louis-Jean (2002). Le marché aux langues. Les effets linguistiques de la mondialisation. Edition Plon.

Castellotti, Véronique \& Moore, Danièle (2002). Social representations of languages and teaching. Guide for the Development of Language Education Policies in Europe. From Linguistic Diversity to Plurilingual Education. Reference Study. Language Policy Division. Council of Europe.

Campos, Roy and Penna, Carlos (2007). Las lenguas extranjeras en México. México rezagado en la materia; sólo el inglés y no generalizado. Encuesta nacional en viviendas. Consulta Mitovsky. Retrieved April 1, 2009 from http://www.consulta.com.mx

Chasan, Marilyn y Phyllis Ryan, "Actitudes de alumnos de inglés hacia la cultura de los nativohablantes del inglés", Estudios de Lingüistica Aplicada, 1995, núm. 21/22. Sociolingüística: Actitudes. Lenguas Europeas: Inglés. Comisión Nacional para el Desarrollo de Pueblos Indigenas (National Commission for 


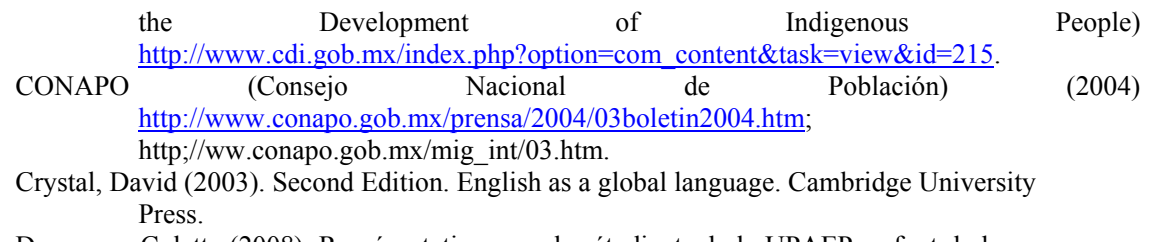

Despagne, Colette (2008). Représentations que les étudiants de la UPAEP se font de leur processus général d'apprentissage et de leur apprentissage de l'anglais : sont-elles propices à l'autonomisation de l'apprentissage de la langue? Unpublished Master's Thesis, Université du Maine, Lettres et Sciences Humaines, France.

Dörnyei, Z. (2003). Attitudes, orientations, and motivations in language learning: advances in theory, research, and applications. In Attitudes, Orientations, and Motivations in Language Learning (pp. 3-32). The best of language learning series. .

Friedrich, Patricia (2003). English in Argentina: attitudes of MBA students. In World Englishes, Vol. 22, No 2, pp. 173-184.

Galtung, J. (1979). "A structural theory of imperialism." In G. Modelski (ed.), Transnational corporations and world order: Readings in international political economy, p. 155-171.

San Francisco: W.H. Freeman and Company.

Gardner, Robert (1985). The role of attitudes and motivation (Social psychology and second language learning). London. E. Arnold.

Görlach, Manfred (2002). English in Europe. Oxford.

Graddol, D. (1997). The Future of English? [Electronic version]. London: The British Council. Retrieved April 1, 2009 from http://www.britishcouncil.org/learning-elt-future.pdf

Hagège, Claude (1996). L'enfant aux deux langues. Editions Jacob, Paris.

Hamel, Rainer Enrique (2006). Bilinglatam Congress. Colombia.

Huguet, Ángel; Lapresta, Cecilo and Madariaga, José M. (2008). A study of Language Attitudes Towards Regional and Foreign Languages by School Children in Aragon, Spain. International Journal of Multilinguism, 5:4, 275-293.

IIE Network (Institute of International Education) (2008). http://www.opendoors.iienetwork.org/page/131575/.

INALI (Instituto Nacional de Lenguas Indígenas) (2008). Catálogo de las Lenguas Indígenas Nacionales: Variantes lingüísticas de México con sus autodenominaciones y referencias geoestadísticas. Diario Oficial, 14 de enero de 2008.

http://www.emexico.gob.mx/wb2/eMex/eMex_Catalogo_de_las_Lenguas_indigenas_Na cionales

Kachru, Braj (1986). The power and politics of English. World Englishes, Vol. 5, No 2/3, pp 121-140.

Kachru, Braj (1990). The Alchemy of English. The spread, Functions, and Models of non-native Englishes. English in the global context. University of Illinois Press.

Kachru, Braj (1992). The Other Tongue. English across Cultures. English in the global context. University of Illinois Press.

Lambert, Wallace (1974). «Culture and language as factors in learning and education». En ABOUD, F. E. y MEADE, R. D. (eds.). The Fifth Western Symposium on Learning. Bellingham, Washington: WesternWashingtonState College.

Lasagabaster, David (2006). Les attitudes linguistiques: un état des lieux. Revue de didactologie des langues-cultures et de lexiculturologie. 2006/4, n 144 , p. 393-406.

López-Gopar, Mario E. (2009). "What Makes Children Different Is What Makes Them Better": Teaching Mexican Children "English" to Foster Multilingual, Multiliteracies, and Intercultural Practices. PhD thesis. Ontario Institute for Studies in Education of the University of Toronto.

Maciel, David (1996). El México olvidado : La historia del pueblo chicano. Universidad Autónoma de Ciudad Juárez, Colección Sin Fronteras. 
McArthur, Tom (1998). The English languages. Cambridge University Press.

Mc Clure, Erica and Mir, Montserrat (1995). Spanish-English Codeswitching in the Mexican and Spanish Press. In Journal of Linguistic Anthropology 5(1): 33-50.

Mitovsky Poll: http://72.52.156.225/Estudio.aspx? Estudio=lenguas-extranjeras.

Moore, Danièle (2007). Les représentations des langues et de leur apprentissage : itinéraires théoriques et trajets méthodologiques. In Moore, Danièle (coordination) (2007). Les représentations des langues et de leur apprentissage (pp. 9-22). Collection C.R.E.D.I.F.. Essais, Ed. Didier.

Niño Murcia, Mercedes (2003). English is like the dollar: hard currency ideology and the status of English in Peru. In World Englishes, Vol. 22, No 2, pp. 121-142.

Pennycook, Alastair (1998). English and the discourse of colonialism. Routledge.

Phillipson, Robert (1992). Linguistic imperialism. Oxford Applied Linguistics. Oxford University Press.

Riley, Philip (1989). Learners' representations of language and language learning. Mélanges pédagogiques. http://revues.univ-nancy2.fr/melangesCrapel/IMG/pdf/6riley-4.pdf

Rodríguez Gómez (2005) http://rodriguez.blogsome.com/campus-134/.

Ryan, Richard M. \& Deci, Edward L. (2000). Self-Determination Theory and the Facilitation of Intrinsic Motivation, Social Development, and Well-Being. American Psychologist. Vol. 55 , No. $1,68-78$.

Santillana, (Ed.) (2008) « Así hablamos » http://www.cepe.unam.mx/imgotros/folleto.html.

Schiller, Herbert (1976). Communication and cultural domination. New York: International Arts and Sciences Press.

Shapiro, M. (1989). A political approach to language purism. In B. Jernudd and M. Shapiro (1995), Quality on the nose, The Sunday Age, 12 February, p. 6.

Skutnabb-Kangas, Tove (1988). Multilingualism and the Education of Minority Children. In Skutnabb-Kangas, Tove \& Cummins, Jim (Eds.).

Sphinx Millenium (2003). Le Sphinx Développement, Parc Altaïs, 74650 Chavanod, France.

Retriewed from http://www.lesphinx-developpement.fr/logiciels/1/sphinx-plus/2/logicielsphinx-plus.html

Stanford Encyclopedia of Philosophy: http://plato.stanford.edu/entries/hume/\#Emp.

Strevens, Peter (1982). World English and the world's Englishes; or, whose langaue is it, anyway? Journal of the Royal Society of Arts 120, 5311: 418-31.

Velez-Rendon, Gloria (2003). English in Colombia: a sociolinguistic profile. In World Englishes, Vol. 22, No 2, pp. 185-198.

Weinreich, Uriel (1953). Languages in contact: Findings and Problems. Publications of the Linguistic Circle of New York.

Colette Despagne is a $\mathrm{PhD}$ student at the University of Western Ontario. Previously she was the director of the Foreign Language Centre at the Autonomous Popular University in the State of Puebla, Mexico (UPAEP) where she was responsible for curriculum development, teaching, and restructuring the Centre to employ the Common European Framework of Reference (CEFR) for language teaching. She can be reached atcdespagn@uwo.ca. 